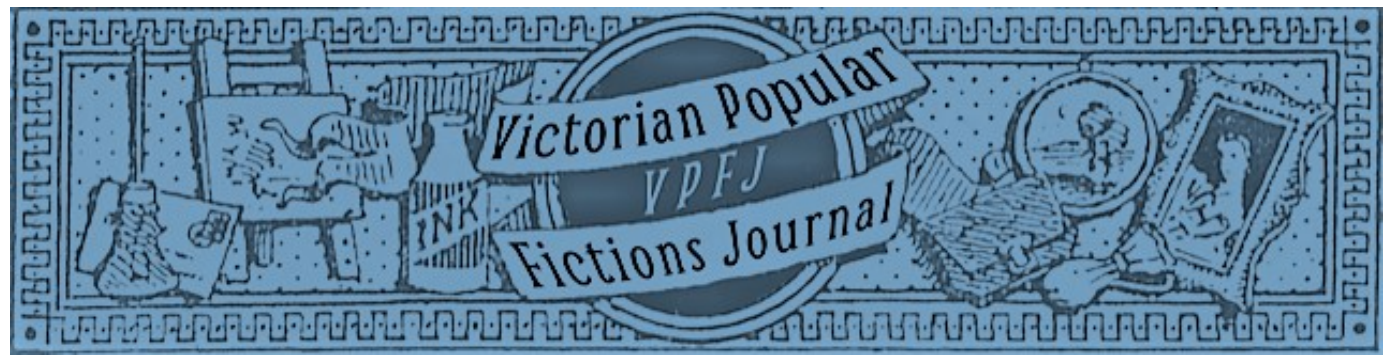

\title{
Maps, Power, and Affect in Richard Jefferies and Anthony Trollope
}

\author{
Andrew Hewitt
}

\begin{abstract}
In Imaginary Cartographies Daniel Smail states: "All maps, linguistic or graphic, are sites for the expression of power." Smail follows Foucault, Harley and others in identifying the map as a form of knowledge-as-power that can be used rhetorically to construct narratives of legitimacy and exclusion as well as instrumentally to support the deployment of force. This generalisation is challenged with examples from Richard Jefferies and Anthony Trollope, both of whom created maps as sites for the expression of affect. The map of his home village drawn by Jefferies in his childhood and recollected at the end of his life in the memoir-essay "My Old Village," and the increasingly complicated linguistic maps of Barsetshire offered in Trollope's "Chronicles" of that imaginary county, are discussed as examples of affect as surplus, that which "exceeds" our powers of rational and linguistic explanation. Although the traces of affective surplus are typically thought of as marking the body, it is also possible to consider maps in Jefferies and Trollope as sites for the capture of affective surplus, generated as the author prepares to take leave (actual or metaphorical) of the represented place. In other words, some maps are best understood as sites for the expression of love.
\end{abstract}

\section{Keywords}

Richard Jefferies; Anthony Trollope; Daniel Smail; Barset; maps; power; affect; emotion; belonging.

Date of Acceptance: 23 December 2019

Date of Publication: 31 December 2019

Double Blind Peer Reviewed

Recommended Citation:

Hewitt, Andrew. 2019. "Maps, Power, and Affect in Richard Jefferies and Anthony Trollope." Victorian Popular Fictions, 1.2: 123-134. ISSN: 2632-4253 (online) DOI: https://doi.org/10.46911/ HQLQ3124

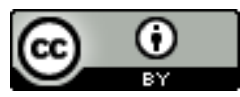

This work is licensed under a Creative Commons Attribution 4.0 International License. 


\title{
Maps, Power, and Affect in Richard Jefferies and Anthony Trollope
}

\author{
Andrew Hewitt
}

All maps, linguistic or graphic, are sites for the expression of power.

(Smail 1999: 8)

\begin{abstract}
Almost the first thing I did with pen and ink as a boy was to draw a map of the hamlet with the roads and lanes and paths, and I think some of the ponds, and with each of the houses marked and the occupier's name. Of course it was very roughly done, and not to any scale, yet it was perfectly accurate and full of detail. I wish I could find it, but the confusion of time has scattered and mixed these early papers.
\end{abstract}

(Jefferies [1889] 2013: 294)

In this essay I contest Daniel Smail's assertion in the epigraph above that "[a]11 maps, linguistic or graphic, are sites for the expression of power" by arguing that some maps, at least, are sites for the expression of affect. Cases in point include the map described by Richard Jefferies in his essay-memoir "My Old Village" (Jefferies [1889] 2013; quoted above); the map of the setting of Jefferies's novel for children, Bevis (1882); and the various maps of Barsetshire given in the novels of Anthony Trollope. The nameless authorities who seek to obliterate Jefferies's map of the "old village" from memory are certainly acting on the assumption that maps express power, but what the memoir demonstrates is the cruelty of this assumption. Trollope's novels contain examples of what we might think of as maps of power, such as the "brilliantly printed" views of the projected route of the South Central Pacific and Mexican Railway used to sway potential investors in a fraudulent scheme in The Way We Live Now (Trollope [1875] 1994: 68). The map of Barsetshire, however, which becomes progressively more detailed over the course of the six "Chronicles," represents the deepening attachment amounting to a kind of topophilia Trollope himself had come to feel for the "dear county" of his own invention (Trollope [1883] 2016: 98). Topophilia, a word coined by W. H. Auden (Harris 2010: 222) and given theoretical stature by Gaston Bachelard (1958) and Yi-Fu Tuan (1974), neatly encapsulates the emotional orientation one may feel towards a place in all its natural, historical, and spiritual associations - the "human value" of "the space we love" (Bachelard [1958] 2014:19). In Framley Parsonage (1861), the urgency of the task of mapping Barsetshire is related to the expansion of the novelist's scope beyond the boundaries of his fictional county: we draw maps, that is, of places we are about to leave.

Before embarking on my analysis of maps in Jefferies and Trollope, however, I need to offer some explanation of what I understand by "power" and "affect" as they relate to the production and use of maps, particularly as I hold these terms in opposition (or, at least, in tension). I will also explain why I call on both Jefferies and Trollope - writers who are not often juxtaposed - to counter the claim that maps must be expressions of power. 


\section{Power, Affect, and Maps}

Although Michel Foucault's "observations on geography and maps were cursory," his general theory of the relationship of knowledge and power or knowledge-as-power nevertheless "provides a useful model" for thinking about cartography (Harley 1988: 279). If knowledge is a form of power, then surely so are maps, which codify knowledge of natural formations, human settlements, transport routes, sites of historic importance, and so on. The geographer J. B. Harley, co-editor of a six-volume History of Cartography (1987-2015), was one of the first to bring Foucault's insights to bear on the discipline:

the surveyor, whether consciously or otherwise, replicates not just the "environment" in some abstract sense but equally the territorial imperatives of a particular political system. Whether a map is produced under the banner of cartographic science - as most official maps have been or whether it is an overt propaganda exercise, it cannot escape involvement in the processes by which power is deployed.

(Harley 1988: 279)

Harley's analysis of the "specific functions of maps in the exercise of power" (Harley 1988: 281) identifies how maps have been and are used to support cadastral or property rights (Smail's concern), the rise of the nation-state, and empire building on a global scale. Maps also contain "silences," exerting "social influence through their omissions as much as by the features they depict and emphasise":

In seventeenth-century Ireland, for example, the fact that surveyors working for English proprietors sometimes excluded the cabins of the native Irish from their otherwise "accurate" maps is not just a question of scale and of the topographical prominence of such houses, but rather of the religious tensions and class relations in the Irish countryside.

(Harley 1988: 291-2)

These "silences" are like Derridean blind spots that reveal the text's contradictions and repressed meanings. Harley also draws on Derrida, for example by attending to the intertextual, rhetorical, and metaphorical dimensions of maps (Harley 1992: 238-43). He concludes that maps and map-makers "do have politics": "all these technical processes [of map-making] represent acts of control over [the world's] image which extend beyond the professed uses of cartography. The world is disciplined. The world is normalized. We are prisoners in its spatial matrix" (Harley 1992: 244-5). As Smail acknowledges in a footnote, the argument that "maps are instruments and reflections of power" is "clearly associated" with the work of both Harley and Foucault (Smail 1999: 3, n6). Others who have explored the relationship between cartography, rhetoric, and power include Michel de Certeau, for whom the activity of mapping involves (though does not end with) creating and dominating otherness (de Certeau [1975] 1988), and Derek Gregory (1994), who introduces his Geographical Imaginations (1994) with the observation that "mapping is necessarily situated, embodied, partial, like all other practices of representation" (Gregory 1994: 7).

There is no question that maps can be used to construct narratives of power and exclusion and be used instrumentally to support the deployment of force. However, as Foucault also said, "where there is power, there is resistance" (Foucault 1978: 95). I want to resist the generalisation that "[a]11 maps ... are sites for the expression of power" with the proposal that some are sites of affect instead. The term "affect" has been so widely deployed in theoretical and critical work in the humanities and social sciences over the last twenty-five years that it risks losing its utility (van Alphen and Jirsa 2019: 1). A "prepersonal intensity" that shapes individual and collective existence (Massumi 2013: xvii), affect is the "something about life," as Ben Anderson puts it, which "exceeds the many ways in which life is known, rendered actionable and intervened in" (Anderson 2014: 92). As these attempts at definition 
show, affect is not easily pinned down. Sara Ahmed proposes a model of orientation and contact: affect is what moves us toward and away from an object, while "the orientations we have toward others shape the contours of space by affecting relations of proximity and distance between bodies" (Ahmed 2006: 2). The notion of affect as bearing on the arrangement in space of bodies and objects is one possible link to cartography. However, my argument in the rest of this paper draws on the figuration of affect as surplus, that which "exceeds" our powers of rational and linguistic explanation. The traces of this affective surplus are typically thought of as marking the body (with blushes, goosebumps, palpitations, weeping) and causing it to move. According to Brian Massumi, affect is "ongoing": the proper name for this "personalized content," this "capture" of affect on the body, is emotion (Massumi 2002: 217). I propose to consider maps in Jefferies and Trollope as sites for the capture, in artefactual form, of this affective surplus - in a sense, as extensions of the body where affect is written up as emotion.

Jefferies and Trollope are not typically considered side by side. There are grounds for comparison - for example, both wrote extensively about the English countryside and rural pursuits such as fox-hunting - but these are not my concern and I am not performing a comparative analysis of them now. The choice of Jefferies and Trollope in the context of an essay about maps is motivated by the fact that both drew graphical maps of the localities (real or fictional) they described linguistically, but chose not to publish them. In this they differ from Thomas Hardy, who published a map of Egdon Heath as the frontispiece of The Return of the Native (1878), and many other writers, especially of adventure stories, who sought to add verisimilitude to their tales by including maps of their settings (Hewitt 2014). In my view, that some writers draw maps "purely for their own purposes" (Irwin 2006: 25) would tend to complicate the idea that maps are sites for the expression of power. My hope is that the examples drawn from Jefferies and Trollope will be enough to make my case for considering some maps as sites for the expression of affect.

\section{Jefferies: Mapping the Lost Village of Childhood}

The nature writer Richard Jefferies (1848-87) established himself at a young age as "as a national figure and a trusted voice on rural matters" (Cocker 2018: n.p.). His spiritual vision of what constituted the truth of mankind's relationship to nature was expressed in his autobiography The Story of My Heart (1883), for which he is still well-known, but it is his essays that are mainly read today; a selection edited by the naturalist Richard Mabey was published by Penguin Classics in 2013. The post-apocalyptic fantasy After London (1885) describes an England reclaimed both by nature and by medieval traditions and social organisation; it has been included on Oxford's list of World's Classics and was recently edited by Mark Frost (2017) for a new generation of eco-conscious readers.

Jefferies dictated "My Old Village" from his sickbed in the last year of his life; it was published after his death in the collection Field and Hedgerow (1889). ${ }^{1}$ It is a deeply personal commemorative essay of the kind at which Jefferies excelled, emerging from recollections of Coate, the Wiltshire village of his birth and childhood, but shot through with anxious intimations of mortality as Jefferies confronts the simultaneously precious and fragile nature

\footnotetext{
${ }^{1}$ See Keith (1965: 164-8) for an excellent discussion of the place "My Old Village" occupies in Jefferies's work.
} 
of his personal past, which will disappear when he does. ${ }^{2}$ The essay contains a memory of Jefferies's earliest work with "pen and ink," namely the mapping of the "hamlet" itself. It begins, however, with a death:

\section{MY OLD VILLAGE}

"John Brown is dead," said an aged friend and visitor in answer to my inquiry for the strong labourer.

"Is he really dead?" I asked, for it seemed impossible.

"He is. He came home from his work in the evening as usual, and seemed to catch his foot in the threshold and fell forward on the floor. When they picked him up he was dead." ... $\mathrm{He}$ is gone through the great doorway, and one pencil-mark is rubbed out.

(Jefferies [1889] 2013: 286)

The very abruptness of the opening suggests that Brown's death is meant to be read as linked to the fate of the village itself, and sure enough, as we discover, "My Old Village" is not so much a trip down memory lane as the story of the almost complete disappearance of a place and a way of life. Indeed, any one of the now-vanished entities mentioned in "My Old Village" could be said to stand for the erasure of the whole:

I think I have heard that the oaks are down. (Jefferies [1889] 2013: 295)

The brooks have ceased to run. (Jefferies [1889] 2013: 295)

There used to be footpaths. (Jefferies [1889] 2013: 295)

The walnut trees are dead. (Jefferies [1889] 2013: 297)

The ash copses are cut, and the hazel mounds destroyed. (Jefferies [1889] 2013: 298)

The death of John Brown, the felling of the oaks, the drying-up of the brooks and so on symbolise the loss of the village itself, the village as the place of childhood, of proximity to nature, of life. But perhaps the most absorbing symbol in "My Old Village" is the child's map. In Jefferies's recollection, this "first thing I did with pen and ink" showed the "houses" that made up the village, each labelled with its "occupier's name," as well as the "roads and lanes and paths" and "ponds." As a map it was "not to any scale" yet "perfectly accurate and full of detail." Is this a paradox? How can a map be "not to ... scale" and at the same time "perfectly accurate"? Perhaps we may infer what Jefferies means by this apparent contradiction from what we know of children's drawing habits. Up to a certain age, when making pictures of their parents for example, children respond to the affective significance of body parts rather than their actual proportions, hence the typically outsized renderings of hands and faces. Thus a child's drawing may be both not to scale and yet accurate in the sense of corresponding to the child's sense of what matters; and a child's map likewise. It is a map, in other words, of an inner emotional landscape rather than an objective representation of the "actual" world - the "accurate" record of an affective engagement with a place rather than an attempt to make it navigable, or even recognisable, for others, as a conventional map might aim to do. In this context we might also recall Thomas Hardy's definition of art as "a disproportioning - (i.e. distorting, throwing out of proportion) - of realities, to show more clearly the features that matter in those realities" (Hardy 1984: 239). The child-Jefferies's map is, in short, a work of art, not of science - or, what may amount to the same thing, a work of affect: an attempt to "capture" the affect orienting the boy towards his home village in the form of a map that imprints his emotion of belonging. To recall Ahmed's words on affect as orientation, the child's map shows him grappling with "the contours of space by affecting relations of proximity and distance between bodies" (Ahmed 2006: 2).

Jefferies explores the childhood pastime of map-making in his novel for children Bevis, in which the eponymous boy-hero is a born cartographer, "always ready to draw maps and

\footnotetext{
${ }^{2}$ For convenience I will refer to the first-person speaker of "My Old Village" as Jefferies, though I accept that the speaker and the writer are not necessarily the same.
} 
plans of all kinds" using whatever materials come to hand - brown paper for wrapping parcels, a fly-leaf torn from a book, "the back of a card that chanced to lie on the table" (Jefferies [1882] 1989: 415). An expedition around the nearby lake is carefully documented:

First Bevis made a semicircle to represent the stony bay where they found the roach, then an angular point for the sandy bar, then a straight line for the shelving shore. ... "Of course there will be names when I have drawn the outline. Here's the cliff." He put a slight projection where the cliff jutted out a little way, then a gentle curve for the shore of the meadow, and began another trending away to the left for the place where they were.

(Jefferies [1882] 1989: 33)

Having promised his friends a "war," he gives equal priority to fashioning weapons, gathering provisions, and drawing up the "map of the coming campaign" showing the roads, the battlefield, and the camps of the opposing armies (Jefferies [1882 ] 1989: 112). So that he will always be able to locate the stars, even in daytime, he studies their position in the night sky relative to the tops of nearby trees and produces in his mind's eye a unique atlas that imaginatively merges heaven and earth (Jefferies [1882] 1989: 289-90). Map-making is as much a part of Bevis's boyhood as swimming, hiking, and learning to shoot.

The Jefferies who draws up a wholly accurate though "not to any scale" map of his hamlet in "My Old Village" is perhaps intended to be younger than the Bevis who maps the straight and curving shores of the local reservoir. In any case, Bevis's imaginative and affective investment in his surroundings does not undermine his ability to map them accurately. Indeed, his uncompromised attention to the actual world is at least as important to his character as the power of his imagination. One might say that it is precisely this commitment to the world around him that allows Bevis to remake it - elevating a modest inland body of water into the "New Sea," for example - without any resulting sense of distortion. In transferring the actual world onto paper Bevis is a figure of the kind of representational artist or realist writer that Jefferies was not. His approach to composition is clear. The outline comes first, then the names. Like "My Old Village," Bevis is set in Wiltshire near Coate reservoir, where Jefferies's own childhood was spent. Comparison of "the Bevis country" (as shown in the maps eventually produced by Jefferies's admirers) with a map of the actual terrain centred on the reservoir explored by Bevis and his companion Mark shows that the topographical element of the fantasy is slight. The water, the island, the canal are all real; the fantasy is in the naming of them. The body of water becomes the "New Sea," a name that clearly signals the boys' discovery and therefore - to the extent that a sea can be owned - their ownership of it. In this sense Bevis's map might be said to bear out Smail's assertion that "[a]11 maps ... are sites for the expression of power." Clearly Bevis's map is related to his sense of possession; mapping a territory, like planting a flag, is a critical stage in asserting control over it. Indeed, Bevis's intuitive grasp of the connection between maps and power is one of the qualities that make him a natural leader.

But Bevis and Mark are, in the end, only boys, and their power is accordingly limited to what can be done with the imagination. Fed by the "Mississippi" and drained by the "Nile," home to the "Straits of Mozambique" and the island of "New Formosa," Bevis's New Sea merges Old and New World, East and West, empire and trade, to provide an all-purpose setting for whatever voyage or adventure the boys might have in mind. Thus his map too could be said to be both "accurate" and drawn to a scale only an adventurous child would recognise. This surfaces most clearly in the naming convention: rivers bear the names of rivers, islands of islands, but affective pressure distorts or disproportions them so that the small and local become the mighty and world-famous. And yet, Bevis's firm grip on actuality means we never feel anything cheap or silly is going on, as we do for example at the end of 
Huckleberry Finn (1884), when Huck succumbs to Tom Sawyer's fantasy of how Jim should be rescued from slavery and almost costs the man his life.

Modern editions of Bevis, like many adventure stories, sometimes come supplied with a map of "the Bevis country" as frontispiece - a realisation of the map that Bevis is described as making in the text. The first such map was drawn by the artist David Garnett at the age of 12 and appeared in the third (1904) edition of Jefferies's novel. There have been other versions, including one by E. H. Shephard. ${ }^{3}$ These executions of the map that Bevis draws are instances of what we might think of today as a kind of fan fiction, that is, additions to the original work by its devoted readers: Jefferies himself did not provide a map. If he did sketch one, it must have been lost. Such at any rate was the fate of the map recalled in "My Old Village."

Like childhood itself, the child-Jefferies's map of his native hamlet has an evanescent quality: subject to the "confusion of time," it slips away from its maker along with other "early papers," testaments of youth, that have become "scattered and mixed." Jefferies acknowledges that as a map his childhood effort would be useless to anyone visiting the site of the old village - not, however, because of its failure to conform to scale, but because the place that inspired it is no more: "A map by Ptolemy would bear as much resemblance to the same country in a modern atlas as mine to the present state of that locality. It is all gone rubbed out" (Jefferies [1889] 2013: 294). The erasure of a mark from a writing surface is explicitly linked to death at the beginning of the essay, where Jefferies says of the death of John Brown: "one pencil-mark is rubbed out." The phrase occurs in a more innocent, literal sense in Bevis when the boys need to correct a diagram of a gun by changing the place of a dot: "'Rub out the dot at C,' said Bevis. 'I haven't got any indiarubber, you suppose it's rubbed out" (Jefferies [1882] 1989: 415). The implications of "rubbed out" in "My Old Village" are more complicated. It is not just that the old village has disappeared from the surface of the earth as completely as a document, such as a map, disappears when you rub it out, though that is the case. The expression has unsettling overtones which are difficult to ignore. As slang for "murdered," it has become familiar from American detective novels and movies of the 1940s, but in fact this meaning is much older and would have been available to Jefferies: it occurs as early as 1816 in Scott's novel Old Mortality in the speech of two soldiers contemplating the contract killing of Lord Evandale:

"[W]ill this fellow - this Basil Olifant - pay handsomely?"

"Like a prince, man," said Inglis; "Evandale is the man on earth whom he hates worst, and he fears him, besides, about some law business; and were he once rubbed out of the way, all, he thinks, will be his own."

(Scott [1816] 2009: 445)

"It was delicious to sit there with a great volume of Sir Walter Scott, half in sunshine, half in shade," Jefferies recalls of the walnut-grove in "My Old Village" (Jefferies [1889] 2013: 297). Whether or not Jefferies had this metaphorical sense of "rubbed out" in mind - whether he meant to imply that the inhabitants of the village have been somehow deliberately targeted for liquidation - the anxiety is palpable. And it makes the "very learned men" who now appear in the essay deeply ambiguous if not downright sinister figures:

\footnotetext{
3 See Daniel (1994) for a detailed discussion of the real geography underlying the novel, reproductions of the maps produced by Garnett, the Winthrop-Youngs, and Daniel himself. E. H. Shepherd illustrated the book and drew a map for the endpapers for the 1932 Jonathan Cape edition.

${ }^{4}$ It is my sense that it is rare for Jefferies to give a negative tilt to the notion of "scattering," which usually has positive connotations related to creation of a pleasing variety and the breaking-up of monotony.
} 
I have been conversing again with learned folk about this place, and they begin to draw my view to certain considerations. These very learned men point out to me a number of objections, for the question they sceptically put is this: are you quite certain that such a village ever existed?

(Jefferies [1889] 2013: 299)

These learned men are practised at mental erasure by means of sowing doubt:

In the first place, they say, you have only got one other witness beside yourself, and she is aged, and has defective sight; ... Secondly, John Brown cannot be found to bear testimony. Thirdly, there are no ghosts there; that can be demonstrated. It renders a case unsubstantial to introduce these flimsy spirits. Fourthly, the map is lost, and it might be asked was there ever such a map? Fifthly, the people are all gone. ... You can't expect grave and considerate men to take your story as it stands; they must consult the Ordnance Survey and Domesday Book. ... I may resent this, but I cannot deny that the argument is very black against me, and I begin to think that my senses have deceived me. It is as they say.

(Jefferies [1889] 2013: 299-300)

It is as if, without documentary or testamentary support, the village itself ceases to exist. The map that is "lost" and therefore cannot be admitted in evidence is contrasted with those totemic works of cartographic reference, the "Ordnance Survey and Domesday Book," which "must" be consulted instead. "Was there ever such a map?" can be heard in two ways: "sceptically," in the tone of the "very learned men" who challenge the map's existence; and in the voice of Jefferies himself as a lament for something wonderful that has been irretrievably lost: was there ever a map more glorious? In either case, the map stands for the village itself, which may be either a false memory (the learned men's opinion), or a vanished paradise (the speaker's view). Map and village are thus made to seem co-dependent: once one has been rubbed out, the other also disappears. Imagining himself logically defeated in this way, Jefferies concedes:

perhaps after all I was mistaken, and there never was any such place or any such meadows, and I was never there. And perhaps in course of time I shall find out also, when I pass away physically, that as a matter of fact there never was any earth.

(Jefferies [1889] 2013: 300).

If it is true then that for Jefferies the map of "My Old Village" is not a site for "the expression of power" but rather the quasi-artistic record of a scene from affective life, it is also true that for the "learned men" the map is perceived as a matter for contest. Denying the existence of the map is a necessary part of demolishing the village itself. We might conclude, then, that part of the tragedy of "My Old Village" arises from the clash of these two points of view. On the one hand, the map is an irreplaceable fragment of childhood, valuable to and interpretable by nobody other than its maker on account of its primary fidelity to affective meaning. On the other, it is evidence, however slight, of a disreputable worldview that values spontaneous emotional connection with the world and the traces this connection leaves (in writing, in maps) more than it values conformity to the official, testable account. It is a flag planted in the soil of imagination which must be pulled up and discarded by those who believe that maps are necessarily "sites for the expression of power," and accordingly feel their own power threatened. With the cancellation of the mark, the thing itself is also cancelled out. A sustained mental act of suppression or denial is enough to seal the fate of a village - at least, to seal it "as a matter of fact" (emphasis added), for Jefferies seems to hint at the barest possibility that the village may continue to exist in some other realm.

\section{Trollope: Mapping the "Dear County" of Barsetshire}


Is the reverse also true? Can a sustained act of imagination bring a place into existence? Jefferies's old village is a real place whose representation is transformed by acts of imagination; Trollope's Barsetshire is an entirely fictional place made to seem real. Certainly Barsetshire has had a more positive afterlife than Jefferies's old village. Framley Parsonage (1861) was the novel that made Anthony Trollope (1815-82) a truly popular author. Its appearance in serial form in the fledgling Cornhill magazine between January 1860 and April 1861 helped bring in over 100,000 subscribers, and secured the new publication's place in the British cultural landscape. ${ }^{5}$ It was also the novel that saw Trollope's fictional county of Barsetshire evolve in depth and complexity to the point where Trollope himself felt that a map was required. Framley Parsonage was the fourth of the "Chronicles of Barsetshire"; in chapter 14, introducing the parish of Hogglestock "in the northern extremity of the eastern division of the county - lying also on the borders of the western division," the narrator declares: "I almost fear that it will become necessary, before this history be completed, to provide a map of Barsetshire for the due explanation of all these localities" (Trollope [1861] 2004: 184). He goes on to place Framley itself ("also in the northern portion of the county, but just to the south of the grand trunk line of railway from which the branch to Barchester strikes off at a point some thirty miles nearer to London"), its station Silverbridge ("which is, however, in the western division of the county"), and other places, before sketching the "general nature of the county":

Barsetshire taken altogether is a pleasant green tree-becrowded county, with large bosky hedges, pretty damp deep lanes, and roads with broad grass margins running along them. Such is the general nature of the county; but just up in its northern extremity this nature alters. There it is bleak and ugly, with low artificial hedges and without wood; not uncultivated, as it is all portioned out into new-looking large fields, bearing turnips and wheat and mangel, all in due course of agricultural rotation; but it has none of the special beauties of English cultivation. ... Indeed the whole parish of Hogglestock should have been in the adjoining county, which is by no means so attractive as Barsetshire; - a fact well known to those few of my readers who are well acquainted with their own country.

(Trollope [1861] 2004: 185)

The allusion to the randomness of county boundaries, with its implication that places should by rights be grouped according to their beauty or ugliness, is a stroke of genius, setting as it does the boundaries for the narrator's own freedom as a supposed chronicler of real life. There is no reason at all why Hogglestock, a fictional place, should not be assigned to any county whatsoever; by making a point of including this bleak region in the otherwise luscious Barsetshire, the narrator proves that he is no whimsical creator of ideal garden-like realms, but subject to the constraints of actuality or at least the truth-claims of realism. If he is to provide the Chronicles of Barsetshire, he must pay due attention to Hogglestock, unfortunate as it may be to have to descend among its agriculturally rotated fields. At the same time, if Barsetshire is, according to the convention adopted by the narrator, a "real" place, why should he "fear" to "provide a map" of it? Surely readers could simply be directed to look up these "localities" for themselves in any decent atlas or gazetteer?

In fact Trollope did have his own map of the county to hand as he wrote Framley Parsonage and the two final instalments of the Chronicles, The Small House at Allington (1864) and The Last Chronicle of Barsetshire (1867), as he records in the Autobiography (1883):

as I wrote it [Framley Parsonage] I became more closely than ever acquainted with the new shire which I had added to the English counties. I had it all in my mind: its roads and railroads,

\footnotetext{
${ }^{5}$ David Skilton and Peter Miles give a good overview of the popular impact of the novel in their introduction to the Penguin Classics edition (Trollope (1861] 2004: 7-12).
} 
its towns and parishes, its members of Parliament, and the different hunts which rode over it ... and as I wrote it I made a map of the dear county. Throughout these stories there has been no name given to a fictitious site which does not represent to me a spot of which I know all the accessories, as though I had lived and wandered there.

(Trollope [1883] 2016: 98)

However, unlike Thomas Hardy's map of Egdon Heath, Trollope's "map of the dear county" was not published in his lifetime: the only maps of Barsetshire available were linguistic rather than graphic. It was left to Trollope's fans to fill the gap. As Michael Sadleir reports: "two enthusiasts - Mr Spencer van Bokkelen Nichols in America, and Father Ronald Knox in England - tried their hand at a reconstruction of the county as Trollope conceived it" (Sadleir 1927: 153). For Knox in particular this required some decisions to address contradictions he found in the various texts. ${ }^{6}$ When Trollope's own graphic map was eventually discovered among his papers after his death, it too was found to contain a number of "mistakes," that is, locations and distances that did not correspond to locations and distances cited in the novels. A version was prepared by Sadleir himself and published in 1927 (Sadleir 1927: 154f); readers may judge for themselves whether the deviations between linguistic and graphic maps are significant. It would be interesting to explore how the "expression of power" is modulated when readers redraw an author's map, particularly when the reader's version attempts to rectify the writer's "mistakes," as is the case with Knox's map of Barsetshire.

What does Trollope's own practice say about maps as "expressions of power"? It is not surprising that maps should feature widely in the works of so well-travelled a writer. Frequently they appear in a satirical context. Framley Parsonage itself contains a map of power, which the philanthropist Harold Smith uses as a visual aid in his lectures to potential donors to the cause he has espoused of bringing "civilisation" to the backward people of the "Southern Ocean":

"On the present occasion," Mr. Smith continued, "our object is to learn something as to those grand and magnificent islands which lie far away, beyond the Indies, in the Southern Ocean; ... Papua and the Philippines, Borneo and the Moluccas. My friends, you are familiar with your maps, and you know the track which the equator makes for itself through those distant oceans." And then many heads were turned down, and there was a rustle of leaves; for not a few ... had brought their maps with them, and refreshed their memories as to the whereabouts of these wondrous islands.

And then Mr. Smith also, with a map in his hand, and pointing occasionally to another large map which hung against the wall, went into the geography of the matter. ... And then, when he had duly marked the path of the line through Borneo, Celebes, and Gilolo, through the Macassar strait and the Molucca passage, Mr. Harold Smith rose to a higher flight. ... "Civilization," he exclaimed, lifting up his eyes and hands to the ceiling. "O, Civilization--"

(Trollope [1861] 2004: 95-7)

In Smith's interpretation, pictured on a map from the other side of the world, the Southern Ocean is a zone ripe for evangelical, Westernising imperialism. Smith seems to appeal to the equator itself as an ally - the equator which "'makes for itself" a "track" that ties all these far-flung places together, a "line" rather like the "grand trunk line" of the railway through Barsetshire (which is, however, "real," given the conventions of the novel, unlike the equator which is only a line in human imagining). It is perhaps the drawing of this line, a mark of over-riding purpose, rather than the map itself that is the sign of power. All the same, Smith's

\footnotetext{
${ }^{6}$ See the London Mercury, 28 (February 1922), in which Knox explains how he has resolved the various inconsistencies he identifies in the texts. Among Knox's many accomplishments was Barchester Pilgrimage (1935), a sequel to Trollope's series.
} 
audience are not impressed: they could have learned just as much out of their own atlases, and stayed at home, Smith's own wife points out unhelpfully (Trollope [1861] 2004: 96).

Another map of power is described in Trollope's great novel of irrational exuberance in the City, The Way We Live Now. The representatives of the fraudulent South Central Pacific and Mexican Railway woo potential investors by displaying "brilliantly printed programmes ... with gorgeous maps" showing the projected route of the new railway, which will run "from the Salt Lake City," branch off "from the San Francisco and Chicago line," and "pass down through the fertile lands of New Mexico and Arizona into the territory of the Mexican Republic" to "the city of Mexico," terminating "on the gulf at the port of Vera Cruz" (Trollope [1875] 1994: 67). Like the equator in Harold Smith's demonstration, the South Central is a fantasy-line of over-riding purpose. It is all a fantasy, but the investors succumb nevertheless, dazzled by the magnitude of the enterprise as conveyed by the map. For the characters who deploy them, in other words, these maps of the Southern Ocean and the Mexican Railway are indeed "sites for the expression of power." For Trollope, however, they are part of the satire.

My argument, however, is that the progressively more detailed linguistic maps of Barsetshire that Trollope gives over the six novels of the Chronicles are an exception to Smail's rule. Unlike maps that seek to lay claim to a territory in support of "civilising" or money-making ventures, the map of Barsetshire represents a kind of surplus arising from the great affection that Trollope had come to feel for the "dear county." Like Jefferies's lost map of the old village, Trollope's map is best appreciated as a site for the expression of love. Framley Parsonage is such a crucial point in its development because it is in this novel that Trollope, steeped as he is by now in "all the accessories" of Barsetshire, finds himself drawn away from the county towards the wider world - specifically, London, whose fashionable and political circles provide the backdrop to a number of key events. Framley Parsonage, P. D. Edwards observes, is different from the three novels that precede it in the sequence in the "extent to which it takes us outside Barset altogether" (Edwards 1978: 43). Although the novel "continues the process by which the boundaries of Barset are broadened to include new social groups," it is "the first of the Barset novels to devote nearly as much attention to the activities of these groups outside Barset as inside" (Edwards 1978: 43). Several of the main characters, including Harold Smith and Nathaniel Sowerby, are Members of Parliament: "it was in London, not in the country, that Mr. Sowerby indulged, if he did indulge, his bachelor mal-practices" (Trollope [1861] 2004: 47). It is in London, too, that Griselda Grantly daughter of Archdeacon Grantly of Barchester and intended by her family to marry into the county aristocracy - comes to the notice of Lord Dumbello, whom she eventually marries (Trollope [1861] 2004: 152). In the earlier novels, London features (if at all) as a place whose values are antagonistic to those of Barsetshire; in Framley Parsonage metropolis and county have fallen into a kind of rhythm: "The hunting season had now nearly passed away, and the great ones of the Barsetshire world were thinking of the glories of London" (Trollope [1861] 2004: 201). Even when Martha Dunstable marries Doctor Thorne, the representative of traditional Barsetshire, she does so on condition that she should continue to reside in London for part of the year. In other words, although the novel in one way only "continues the process" of broadening the canvas of the Barsetshire Chronicles to take in other settings, in another it represents a new development: Barsetshire is no longer a self-sufficient world but is revealed as enmeshed with London.

In short I am suggesting that the task of mapping Barsetshire becomes an explicit requirement in Framley Parsonage not just for practical reasons - because his own creation is becoming too large for Trollope, let alone any reader, to hold in the mind, complete, at one time - but because Framley Parsonage represents the moment that Trollope begins to leave 
his own "dear county" behind. Although there were still two Barsetshire Chronicles to come, Trollope was already beginning to turn to his second great subject, the life of the political classes as represented in the Palliser novels. Unlike his evangelising or money-making characters, who use maps to prop up their dubious or outright fraudulent schemes, Trollope's activity of mapping Barsetshire is a step towards relinquishing it. Map-making is a part of this leave-taking, a distillation of affect in artefactual form.

\section{Conclusion: Power and power?}

Both Trollope and Jefferies, then, afford examples of maps that complicate Smail's assertion. Not all maps are "sites for the expression of power": some are motivated by affective bonds and represent the "capture" or trace of affect in emotional artefacts triggered by scenarios of impending loss or departure.

It could be argued that the maps I have singled out in this essay as sites for the expression of affect are simply expressing power of a different kind - for example, the power of the artist over their creation. I cannot finally refute this, except to say that I do not believe this is what Smail, or Foucault, or Harley, have in mind when they write about "power." It is true that the term "affect" as used in affect theory derives ultimately from Spinoza, for whom affectus is related to potentia, a word translated as "power" (Spinoza [1677] 1996). However, Spinoza also uses another word, potestas, also rendered into English as "power." Where potestas "refers to power in its fixed, institutional or "constituted' form," potentia "refers to power in its fluid, dynamic or 'constitutive' form" (Negri 2004: xv). In translating Spinoza, Antonio Negri solves the problem orthographically by writing the former as "Power" and the latter as "power" (Negri 2004: 15). Upper-case "Power" is (among other things) what lays claim to territory, underwrites the state, keeps order, decides questions of ownership and responsibility. Lower-case power is (among other things) what orients people towards places and each other. Were we to adopt this practice of distinguishing the two, we might rewrite Foucault's epigram as "where there is Power, there is resistance" (or even, "where there is Power, there is power"), and Smail's generalisation as "[a]ll maps [...] are sites for the expression of Power." We could then concede that the maps of Jefferies's old village and Trollope's Barsetshire are sites for the expression of affect-power. It is not the power their makers have or claim over these places, but the power these places have over their makers, felt most keenly as the knowledge of the moment of necessary departure dawns.

\section{Bibliography}

Ahmed, Sara. 2006. Queer Phenomenology: Orientations, Objects, Others. Durham, NC: Duke University Press.

Anderson, Ben. 2014. Encountering Affect: Capacities, Apparatuses, Conditions. Abingdon: Ashgate. Bachelard, Gaston. [1958] 2014. The Poetics of Space. New York: Penguin.

Cocker, Mark. 2018. 'Richard Jefferies: A Naturalist under the Microscope'. Spectator.co.uk, 3 February 2018 (online resource; no page). https://www.spectator.co.uk/2018/02/richardjefferies-a-naturalist-under-the-microscope/. Accessed 8 November 2019.

Daniel, Mark. 1994. “The Bevis Country.” Richard Jefferies Society Journal, 3: 16-28.

de Certeau, Michel. [1975] 1988. The Writing of History, translated by Tom Conley. New York: Columbia University Press.

Edwards, P. D. 1978. Anthony Trollope: His Art and Scope. New York: St Martin's Press. 
Foucault, Michel. 1978. The History of Sexuality. Volume I. An Introduction. New York: Vintage Books.

Gregory, Derek. 1994. Geographical Imaginations. Oxford: Blackwell.

Hardy, Thomas. 1984. The Life and Works of Thomas Hardy, edited by Michael Millgate. London: Macmillan.

Harley, J. B. 1988. "Maps, Knowledge and Power." In The Iconography of Landscape, edited by D. Cosgrove and S. Daniels, 277-312. Cambridge: Cambridge University Press.

Harley, J. B. 1992. "Deconstructing the Map." In Writing Worlds: Discourse, Text and Metaphor in the Representation of Landscape, edited by T. J. Barnes and J. S. Duncan, 231-47. London: Routledge.

Harris, Alexandra. 2010. Romantic Moderns: English Writers, Artists and the Imagination from Virginia Woolf to John Piper. London: Thames and Hudson.

Hewitt, Andrew. 2014. "The Castaways of Egdon Heath: The Return of the Native as Island Narrative." Thomas Hardy Journal, 30 (Autumn): 102-20.

Irwin, Michael. 2006. "Maps of Fictional Space." In Literature and Place 1800-2000, edited by Peter Brown and Michael Irwin, 25-48. Bern: Peter Lang.

Jefferies, Richard. [1885] 2017. After London: or, Wild England, edited by Mark Frost. Edinburgh: Edinburgh University Press.

Jefferies, Richard. [1882] 1989. Bevis: The Story of a Boy, edited by Peter Hunt. Oxford: Oxford University Press.

Jefferies, Richard. [1889] 2013. "My Old Village." In Landscape with Figures: Selected Prose Writings, selected and introduced by Richard Mabey, 286-300. London: Penguin.

Keith, W. J. 1965. Richard Jefferies: A Critical Study. Toronto: University of Toronto Press.

Knox, Ronald. 1935. Barchester Pilgrimage. London: Sheed and Ward.

Massumi, Brian. 2002. Parables for the Virtual: Movement, Affect, Sensation. Durham, N.C.: Duke University Press.

Massumi, Brian. 2013. "Notes on the Translation." In A Thousand Plateaus: Capitalism and Schizophrenia, by Gilles Deleuze and Felix Guattari, translated by Brian Massumi, xvi-xix. London: Bloomsbury.

Negri, Antonio. 2004. Subversive Spinoza: (Un)contemporary Variations. Manchester: Manchester University Press.

Sadleir, Michael. 1927. Trollope: A Commentary. London: Constable.

Scott, Walter. [1816] 2009. Old Mortality, edited by Peter Davidson and Jane Stevenson. Oxford: Oxford University Press.

Smail, Daniel Lord. 1999. Imaginary Cartographies: Possession and Identity in Late Medieval Marseille. Ithaca, NY: Cornell University Press.

Spinoza, Benedict de. [1677] 1996. Ethics. Translated by Edwin Curley. London: Penguin.

Trollope, Anthony. [1883] 2016. An Autobiography and Other Writings. Oxford: Oxford University Press.

Trollope, Anthony. [1861] 2004. Framley Parsonage, edited by David Skilton and Peter Miles. London: Penguin.

Trollope, Anthony. [1875] 1994. The Way We Live Now, edited by Frank Kermode. London: Penguin.

Tuan, Yi-Fu. 1974. Topophilia: A Study of Environmental Perception, Attitudes and Values. Englewood Cliffs, NJ: Prentice-Hall.

Van Alphen, Ernst, and Jirsa, Tomáš. How To Do Things with Affects. Leiden: Brill/Rodopi, 2019. 